\title{
Investigation of anti-HIV activity, cytotoxicity and HIV integrase inhibitory activity of polyherbal formulation $\mathrm{BH}$ extracts
}

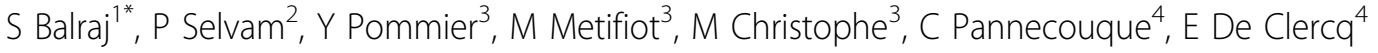 \\ From 2nd International Science Symposium on HIV and Infectious Diseases (HIV SCIENCE 2014) \\ Chennai, India. 30 January - 1 February 2014
}

\section{Background}

HIV integrase (IN) plays important roles at several steps, including viral DNA nuclear import, targeting viral DNA to host chromatin and integration. Identification of novel inhibitors of HIV Integrase has emerged as promising antiviral agents for the treatment of HIV/AIDS. Present work is to investigation of anti-HIV activity and HIV integrase inhibitory activity of various extracts of polyherbal formulation $\mathrm{BH}$.

\section{Method}

Polyherbal extracts (BH) were tested for anti-HIV activity against HIV-1 and -2 in MT-4 cells and cytotoxicity also tested against uninfected MT-4 cells. BH extracts were investigated for inhibition of HIV integrase enzymatic activity to understand the mechanism of antiviral action.

\section{Results}

All extracts exhibited inhibitory activity against HIV-1 integrase (3'P IC $50: 8.8-63 \mu \mathrm{g} / \mathrm{mL}$ and ST IC $50: 4.9-65 \mu \mathrm{g} / \mathrm{mL}$ ). The ethanolic extract (BH-HT) displayed significant inhibitory activity against both step of HIV in enzymatic activity (3'P IC $50: 8.8 \mu \mathrm{g} / \mathrm{mL}$ and ST IC $50: 7.5 \mu \mathrm{g} / \mathrm{mL}$ ). The ethanolic extract also inhibits the HIV-1 replication at the concentration of $59.30 \mu \mathrm{g} / \mathrm{mL}$ and cytotoxicity was found to be more than $>125 \mu \mathrm{g} / \mathrm{mL}$.

\section{Conclusion}

All the extracts inhibit the HIV integrase activity and ethanolic extract inhibit HIV and Integrase enzyme.

\author{
Authors' details \\ ${ }^{1}$ Hans Rover Herbal Clinic, Perambalur, Tamil Nadu, India. ${ }^{2}$ Nova College of \\ Pharm. Edu and Research, Jupudi, AP, India. ${ }^{3}$ Laboratory of Molecular \\ Pharmacology, NCl, Mary Land, USA. ${ }^{4}$ Rega Institute for Medical Research, \\ Leuven, Belgium.
}

Published: 27 May 2014

doi:10.1186/1471-2334-14-S3-O23

Cite this article as: Balraj et al:: Investigation of anti-HIV activity, cytotoxicity and HIV integrase inhibitory activity of polyherbal formulation BH extracts. BMC Infectious Diseases 2014 14(Suppl 3):O23.

* Correspondence: rareindianherbals@gmail.com

${ }^{1}$ Hans Rover Herbal Clinic, Perambalur, Tamil Nadu, India

Full list of author information is available at the end of the article

Submit your next manuscript to BioMed Central and take full advantage of:

- Convenient online submission

- Thorough peer review

- No space constraints or color figure charges

- Immediate publication on acceptance

- Inclusion in PubMed, CAS, Scopus and Google Scholar

- Research which is freely available for redistribution
C Biomed Central 